\title{
Characteristics of Apple Juice and Sugar Infused Fresh and Frozen Blueberries
}

\author{
Felix Akharume ${ }^{1}$, Kaushlendra Singh ${ }^{1}$, and Litha Sivanandan ${ }^{2}$ \\ ${ }^{1}$ School Natural Resources, West Virginia University, Morgantown, USA \\ ${ }^{2}$ Extension Service, West Virginia University, Morgantown, USA \\ (Corresponding Author: Kaushlendra Singh, 322 Percival Hall, PO: 6125, Morgantown, \\ WV 26505-6125, Email: Kaushlendra.Singh@ mail.wvu.edu)
}

\begin{abstract}
Use of apple juice concentrate and standard sugar-based osmotic solution were compared during osmotic dehydration (OD) of fresh and frozen blueberries for solid gain and water loss. Additionally, fresh and frozen blueberries were characterized for moisture desorption using a thermo-gravimetric analyzer (TGA) at an isothermal temperature of $105^{\circ} \mathrm{C}$ under dry nitrogen condition. Weight loss-time data generated from the TGA was used to calculate the overall liquid diffusion coefficient during moisture desorption. Results showed that the use of apple juice concentrate as an osmotic solution increased sugar concentration of frozen blueberries to 30.30 ${ }^{\circ}$ Brix, which was similar to that obtained from the use of sugar-based osmotic solution (32.90 ${ }^{\circ}$ Brix). Additionally, irrespective of the osmotic solution type, the osmotically dehydrated frozen blueberries reached the desired safe water activity $\left(a_{w}\right)$ range $(0.40-0.50)$ in the 600 min drying time during follow-up drying at $74{ }^{\circ} \mathrm{C}$. Moisture desorption characterization using TGA showed that fresh blueberries took about 53\% additional drying time compared to frozen blueberries.
\end{abstract}

Key words: Blueberries, Osmotic Dehydration, Thermogravimetric Analysis, Air Drying, Sugar Solution, Apple Juice 
1

2

3

5 6 in 2014 (USDA, 2015).

7 Owning to their short shelf life, blueberries have to be preserved to ensure availability all year

\section{Introduction}

Blueberries (Vaccinium Corymbosum L.) are a high economic value but highly perishable fruit. They are widely consumed for their nutraceutical and nutritive value (Jimenez-Garcia et al., 2013; Martineau et al., 2006; Nile \& Park, 2014; Shi et al., 2008a). The United States is by far the largest producer of blueberries, with a total production (wild and cultivated) of 309 kilotons

round. Direct air-drying, via convection, is one of the widely used methods for preserving blueberries. However, direct air-drying of blueberries requires a prolonged drying time, high energy input, and may lead to non-uniform quality of the final product (Liping, 1998; VegaGálvez et al., 2012). To improve the quality, reduce the drying time, and minimize overall energy cost of the dried fruit, direct air-drying is generally preceded by the combination of predrying treatments, such as blanching, freezing, osmotic dehydration (OD), enzymes treatments, and chemical treatments (Vega-Gálvez et al., 2012). Osmotic dehydration (OD) is being widely applied as a pretreatment because it minimizes energy consumption and improves the quality of fruit due to reduced heat damage to the fruit's texture, enhanced color, and increased retention of volatiles (Ketata et al., 2013; Azarpazhooh \& Ramaswamy, 2010; Shi et al., 2008a). Water removal and sugar uptake in the fruit during OD process are influenced by size of the fruit (Shi et al., 2008b), pretreatments with chemical agents (Ketata et al., 2013; Kucner et al., 2013), contact time and temperature (Nsonzi \& Ramaswamy, 2008), and type of osmotic agents (Shi. et al 2009; Kucner et al., 2013; Shi et al., 2009; Yadav and Singh, 2014). 
Traditionally, six-carbon dominant sugars (sucrose) are widely used for making osmotic solutions; however, their use renders dried product sugar-rich, a dietary concern among consumers striving to reduce calorie intake from added-sugar. We visualize substituting sucrose with the 5-carbon sugars present in most fruit-juices, for example, apple juice concentrate. Very sparse scientific data is available on the use of apple juice concentrate as an osmotic agent for osmotic dehydration of sour cherries, blackcurrants, and apples (Konopacka et al., 2008; Konopacka et al., 2009) and use of fruit juices during osmotic dehydration of blueberries has not been reported. Konopacka et al. (2008) compared the usefulness of selected fruit juices (concentrated apple juice, mixture of concentrated apple juice and sour cherry juices, and deacidified concentrated apple juice) with traditional sucrose solution during osmotic dehydration of cherry fruit. They reported that the increase in dry matter content of cherry fruit after $2 \mathrm{~h}$ of OD using $60^{\circ}$ Brix osmotic solutions, was statistically similar irrespective of type of osmotic solution (fruit juices or sucrose) (Konopacka et al., 2008). However, types of osmotic solution (sucrose, concentrated apple juice, de-acidified and desalted concentrated apple juices, sorbitol, etc.) and types of fruit (sour cherries, blackcurrants, and apples) have significant effect on water loss and dry matter uptake during $1 \mathrm{~h}$ long OD performed using $65^{\circ}$ Brix osmotic solutions (Konopacka et al., 2009). However, it is not clear if contact time of $1 \mathrm{~h}$ or $2 \mathrm{~h}$ were sufficient to reach equilibrium during the OD processes for sour cherries, blackcurrants, and apples fruits. The purpose of this research was to compare the use of apple juice concentrate and sucrose solutions as osmotic agents during osmotic dehydration of blueberries (fresh or frozen) for contact time equivalent to equilibrium period. The equilibrium period is defined as the time from the start of subjecting fruit to the OD process until no further change in ${ }^{\circ}$ Brix of either fruit or 
44 osmotic solution takes place. Additionally, the research characterized fresh and frozen

45 blueberries for moisture desorption behavior.

\section{2. Materials and Methods}

47 loss through evaporation during heating.

\subsection{Blueberries and Osmotic Agents} were used without thawing.

Fresh blueberries (Bleuets, distributed by Sunbelle Inc. Miami FL. USA) and frozen blueberries (Blue Crop and Blue Jay varieties, distributed by Kroger Co. Cincinnati OH. USA) were purchased from a retail store. The fresh blueberries were stored below $4{ }^{\circ} \mathrm{C}$ in a refrigerator and frozen blueberries were stored in a freezer below $-18{ }^{\circ} \mathrm{C}$ prior to use. For the purpose of physical characterization and moisture desorption characterization experiments, the frozen blueberries were thawed at room temperature for $2 \mathrm{~h}$ and blotted with tissue paper to remove excess water before use. However, for the osmotic dehydration treatment the frozen blueberries

To make the various osmotic solutions, granular sugar (Psst brand, distributed by Kroger Co. Cincinnati OH. USA) and apple juice concentrate (Kroger 100\% apple juice frozen concentrate, distributed by Kroger Co. Cincinnati OH. USA) were purchased from a retail store. The apple juice concentrate had an initial sugar concentration of $42 \pm 2{ }^{\circ}$ Brix. Therefore, osmotic solutions from granular sugar were prepared at the same $42 \pm 2{ }^{\circ}$ Brix concentration. About $252 \mathrm{~g}$ granular table sugar was thoroughly mixed $348 \mathrm{~g}$ of deionized distilled water in a conical flask. For quick solubility of the sugar, the solution was heated to a temperature of $100{ }^{\circ} \mathrm{C}$ and then cooled to room temperature prior to use. A cover of poly-film metallic foil was used to prevent solution 
67 The three significant axial dimensions (Fig. 1) of 100 randomly-selected fresh and frozen 68 (thawed) blueberries were measured using an electronic Vernier caliper (least count $0.02 \mathrm{~mm}$ ).

69 Effective diameter $\left(\mathrm{D}_{\mathrm{e}}\right)$, sphericity $(\phi)$, aspect ratio $\left(R_{A}\right)$ and surface area $\left(S_{A}\right)$ were calculated 70 71 Mohsenin, 1986; Omobuwajo, 1999):

72

73

74

75

76

77 diameter (mm).

$78 \quad$ Fig. 1.

79 Additionally, the fresh and frozen (thawed) blueberries were characterized for moisture content,

80 bulk density, true density, and volumetric moisture compression. The dried samples of fresh and

81 frozen blueberries were also tested for volumetric shrinkage, bulk density and true density. Both

82 fresh and frozen blueberries were assayed for initial moisture content according to the AACC

83 method 44-15A (Moisture - Air-Oven Methods) (AACC, 2000). The bulk density of fresh as

84 well as oven-dried blueberries was measured according to ASTM standard (ASTM C29/C29M -

85 2009). To measure the true density, the actual volume of the samples excluding pore volume, 
was measured using a multipycnometer (Model: MVP.6DC, Quantachrome, Boyton Beach, FL. USA). Volumetric shrinkage was calculated using equation 5.

$$
\text { Volumeric Shrinkage }=\frac{V_{\text {Green }}-V_{\text {oven-dry }}}{V_{\text {oven }- \text { dry }}} \times 100
$$

$$
\text { Additionally, volumetric compression of water present in the blueberries was calculated by }
$$
following equation 6 .

Volumetric Compression of Water $=\frac{\left(m_{\text {Green }}-m_{\text {Oven-dry }}\right) / \rho_{\text {water }}-\left(V_{\text {Green }}-V_{\text {Oven-dry }}\right)}{\left(m_{\text {Green }}-m_{\text {Oven-dry }}\right) / \rho_{\text {Water }}} \times 100(6)$

In this equation, $m_{\text {Green }}$ is the weight of the fresh sample $(\mathrm{g}), m_{\text {Oven-dry }}$ is the weight of an oven-dried sample $(\mathrm{g}), \rho_{\text {Water }}$ is the density of water $\left(\mathrm{g} / \mathrm{cm}^{3}\right), \mathrm{V}_{\text {Green }}$ is the volume of the green sample $\left(\mathrm{cm}^{3}\right)$, and $V_{\text {Oven-dry }}$ is the volume of the oven-dried sample $\left(\mathrm{cm}^{3}\right)$.

\subsection{Moisture Desorption Characteristics}

To investigate the drying characteristics of the samples, drying of fresh and frozen blueberries samples was carried out in a Thermogravimetric analyzer (TGA) (Model: TGA 701, LECO Corporation, IL) under constant nitrogen flow at the isothermal temperature of $105^{\circ} \mathrm{C}$. About 8 mg of sample, replicated twice, was placed in a TGA crucible. The samples were heated from room temperature to $105^{\circ} \mathrm{C}$ at the rate of $16^{\circ} \mathrm{C} / \mathrm{min}$ under constant dry nitrogen flow to keep the relative humidity zero following an ASTM standard (ASTM D7582, 2015). During the heating as well as during the isothermal drying, the weight of the sample, duration, and furnace temperature were recorded in a computer connected to the TGA. The weight-time-temperature data was further processed to produce drying characteristics curves (rate of weight loss as a function of time, moisture ratio or mean moisture content) and to calculate overall liquid diffusion coefficients. 
109 The moisture content was calculated on a dry-basis as follows:

110

$$
M C_{i}=\frac{m_{i-m_{f}}}{m_{f}} \times 100
$$

111 Where $M C_{i}$ is the dry-basis moisture content at $i^{\text {th }}$ time $(\mathrm{g} / 100 \mathrm{~g} \mathrm{~d} . \mathrm{b}), m_{i}$ is the sample weight at $112 i^{\text {th }}$ time $m_{f}$ is the final (weight of dry solid) sample weight $(\mathrm{g})$. For further calculations, 113 fractional moisture content and drying rate $(d X / d t)$, were calculated according to equations (8 114 and 9) according to (Geankoplis, 2003).

$$
X_{i}=\frac{M C_{i}}{100}
$$

$$
D R=\frac{d X}{d t}=\frac{X_{i-1}-X_{i}}{t_{i}-t_{i-1}}
$$

117 Where $X_{i}$ is moisture fraction at $i^{\text {th }}$ time $\left(\frac{\text { gof water }}{g \text { of drysolid }}\right), d X / d t$ is drying rate $118\left(\frac{\text { gof water }}{\text { gof dry solids.min }}\right)$ between $(i-1)^{\text {th }}$ and $i^{\text {th }}$ time intervals and at mean moisture fraction of $119\left(\frac{X_{i-1}+X_{i}}{2}\right)$

120 To compare drying behaviors of samples having different initial moisture contents, the 121 moisture ratio was calculated to normalize moisture content at the $i^{\text {th }}$ interval with initial 122 moisture contents, as given below (Chen et al., 2012)

$$
M R=\frac{M C_{i}-M C_{e}}{M C_{0}-M C_{e}}
$$


124 Where $M C_{0}$ is initial moisture content, $M C_{i}$ moisture content at $i^{\text {th }}$ time $t$, and $M C_{e}$ is the 125 Equilibrium Moisture Content (EMC), which is zero under the current experiments according to 126 the ASTM standard (ASTM D7582, 2015). The TGA equipment uses a dry nitrogen atmosphere 127 and prescribed temperature of $105^{\circ} \mathrm{C}$ to dry any material to bone-dry conditions. However, the 128 bone-dry state of material might not by achieved when it is dried in air of varying humidity and 129 temperatures $\left(60^{\circ} \mathrm{C}\right.$ to $\left.80^{\circ} \mathrm{C}\right)$, where only EMC are reached. EMC depends on type of material 130 being dried, air temperature, and relative humidity. To reach bone-dry material all free water and 131 bound water (capillary condensation, polymolecular adsorption, and monomolecular adsorption) 132 must be removed. For example, air-drying of blueberries at $60{ }^{\circ} \mathrm{C}, 70{ }^{\circ} \mathrm{C}$ and $80{ }^{\circ} \mathrm{C}$ using inlet 133 relative humidity of $62.0 \pm 5.2 \%$ (not inside drying chamber) had resulted in the EMC of $0.031 \mathrm{~g}$ 134 water/g dry solid, $0.027 \mathrm{~g}$ water/g dry solid and $0.026 \mathrm{~g}$ water/g dry solid, respectively (Vega135 Gálvez et al., 2009). In this case, relative humidity values in the drying chamber would have 136 been lower than the inlet relative humidity but also different for each drying temperature, 137 probably not sufficient to remove all types of bound water (Vega-Gálvez et al., 2009).

138 Overall liquid diffusion was assessed from the TGA data according to the procedure outlined 139 by (Geankoplis, 2003). According to the procedure, the drying process of biological materials 140 mostly occurs in the falling rate period. Fick's second law of diffusion (Eqn. 11) (Chen et al., 141 2012) has been extensively used to describe the drying process and interpret drying data. The 142 mathematical solution of Fick's second law for diffusion for spherical bodies is shown in 143 Equation (12) (Azarpazhooh \& Ramaswamy, 2010):

$$
\frac{\partial M R}{\partial t}=\nabla\left[D_{e f f}(\nabla M R)\right]
$$

$$
M R=\frac{6}{\pi^{2}} \sum_{n=1}^{\infty} \frac{1}{n^{2}} \exp \left(-\frac{n^{2} \pi^{2} D_{e f f} t}{r^{2}}\right)
$$


146 Where $n$ is a positive integer, $t$ is the drying time(s), $D_{e f f}$ is overall liquid diffusion coefficient

$147\left(\mathrm{~m}^{2} / \mathrm{s}\right)$, and $r$ is the effective radius of the blueberries $(\mathrm{m})$.

148 When the sample shrinkage is negligible, initial moisture distribution is uniform, and constant 149 moisture diffusivity is assumed, Equation (12) is suitable for determining the $D_{\text {eff }}$. This equation 150 could be further simplified into Equation 13 by taking the first terms of the series solution for 151 long drying times (Ramaswamy \& Nsonzi, 1998; Shi et al., 2008a)

$$
\ln (M R)=\ln \left(\frac{6}{\pi^{2}}\right)-\left(\frac{\pi^{2} D_{e f f}}{r^{2}} t\right)
$$

153 Effective liquid diffusivities are typically determined by plotting experimental drying data in 154 terms of $\ln (M R)$ versus time. From equation (13), a plot of $\ln (M R)$ versus drying time, gives a 155 straight line with a slope $\left(K_{o}\right)$

$$
K_{o}=\frac{\pi^{2} D_{e f f}}{r^{2}}
$$

\subsection{Osmotic Dehydration Experiments}

159 Osmotic dehydration was facilitated by soaking a desired fruit sample in an osmotic solution at a constant incubation temperature of $50{ }^{\circ} \mathrm{C}$. The fruit-to-solution weight ratio was targeted at 1:3.

161 In a typical osmotic dehydration experiment, about $200 \mathrm{~g}$ of fruit sample was placed in about 600

$162 \mathrm{~g}$ of the hot osmotic solution. The pre-formulated osmotic solution was heated up quickly to a 163 designated temperature $\left(100{ }^{\circ} \mathrm{C}\right)$ before the blueberries were immersed. The fruit-solution 164 mixtures were cooled to the target temperature of $50{ }^{\circ} \mathrm{C}$ before transferring to a Lab Line 165 Imperial III incubator (Model: 305, Thermo-scientific, IA. USA). Agitation in the incubator was 166 provided by a platform shaker (Model: EXCELLA E2, New Brunswick Scientific Co. NJ. USA) 
167 set at $50 \mathrm{rpm}$. Sugar concentrations of the solution and blueberries were measured at intervals of

$1681 \mathrm{~h}$ by means of a Reichert Digital Refractometer, according to the method of Association of 169 Official Analytics Chemist (AOAC) 990.35(Shi et al., 2009). After the blueberry sugar 170 concentration became constant (equilibrium period), the blueberries were removed from the 171 solution and rinsed with tap water for $30 \mathrm{~s}$ on a rubber mesh. They were then blotted with tissue 172 paper to remove excess water. The final weight of the sample was recorded.

173 Solid gain ( $S G, \mathrm{~g}$ solid/g dry solid), and water loss (WL, g water/g dry solid) were calculated 174 according to (Liping, 1998; Shi et al., 2009) as follows:

$$
\begin{aligned}
& S G=\frac{W *(1-M)}{W_{o} *\left(1-M_{o}\right)}-1 \\
& W L=\frac{W_{o} * M_{O}-W * M}{W_{o} *\left(1-M_{o}\right)}
\end{aligned}
$$

177 Where $M$ is the fractional moisture content of the sample after osmotic dehydration on a wet 178 basis $(\mathrm{g} / \mathrm{g}), M_{o}$ is the initial fractional moisture content of the sample on a wet basis $(\mathrm{g} / \mathrm{g}), W$ is 179 the weight of the sample after osmotic dehydration $(\mathrm{g}), \mathrm{W}_{\mathrm{o}}$ is the weight of the sample before 180 osmotic dehydration $(\mathrm{g})$.

\subsection{Air-Drying of Osmotically Dehydrated Blueberry Samples}

183 Osmotically dehydrated fruit samples were placed on tray and further air dried in a fruit 184 dehydrator (Model: 3900T, Excalibur Products, CA. USA) in a climate-controlled room 185 maintained at ambient condition of relative humidity (43.00 $\pm 5.00 \%)$ and temperature $186\left(21.10 \pm 2.00^{\circ} \mathrm{C}\right)$. During air-drying, the fruit dehydrator was maintained at $74{ }^{\circ} \mathrm{C}$. Only two of 187 the dehydrator trays were used in the drying for efficient hot air circulation. The trays were 188 placed in the middle of the dehydrator cabinet, directly facing the blower and separated one step 
189 from each other. Osmotically dried blueberries were spread uniformly on the tray and the trays 190 were rotated clockwise at every $1 \mathrm{~h}$. Moisture content and water activity were measured at 191 intervals of $1 \mathrm{~h}$. The water activity was measured using a water activity meter (Model: Aqua Lab 192 Water Activity Meter series 3TE, Decagon Devices, Inc. WA. USA.). Additionally, moisture 193 content was measured by recording the weight loss of a "20 g weighted representative sample", 194 taken from the bulk sample, during drying. Air-drying was considered complete when the water 195 activity reached a range of 0.45-0.5. Additionally, a representative air-dried sample was further 196 oven-dried at $105^{\circ} \mathrm{C}$ for $24 \mathrm{~h}$ to measure moisture content of air-dried samples.

\subsection{Experimental design}

199 A completely randomized design was applied for the experiment. To compare osmotic 200 dehydration of fresh and frozen blueberries, two treatments of fruit type (fresh and frozen 201 blueberries) were considered with three replications $(\mathrm{N}=6)$ for the pre-determined response 202 variables (osmotic dehydration time, solid gain, water loss, and air-drying durations). To 203 compare the influence of osmotic solutions, two treatments of osmotic solution type (sugar-based 204 and apple juice concentrate based osmotic solutions) with three replications $(\mathrm{N}=6)$ were 205 considered for the same response variables. Microsoft Excel 2010 was used in summarizing and 206 generating graphs. The $t$-test procedure in SAS statistical software (University Edition) was used 207 in performing a $t$ test (at $95 \%$ confidence interval).

\section{Results and Discussion}


The fresh and frozen blueberry samples were assessed for the following physical

211

212

213

214

215

216

217

218

219

220

221

222

223

224

225

226

227

228

229

230

231

232 characteristics: moisture content, shape characteristics, bulk and true densities. In addition, the same samples were oven-dried, with volumetric shrinkage, moisture compression, and bulk and true densities under dry conditions calculated. Results of all physical characteristics are presented in Table 1. The fresh and frozen blueberry samples used in this study had moisture contents of $5.16 \mathrm{~g}$ water/g of dry solids and $5.70 \mathrm{~g}$ water/g of dry solids respectively, and upon thawing, the moisture content of frozen berries reduced to $4.30 \mathrm{~g}$ water/g of dry solids, a $25 \%$ decrease. Similar values for moisture content were reported by other authors: $5.67 \mathrm{~g}$ water/g dry solid for both fresh and frozen blueberries (Shi et al., 2008a); 5.28g water/g of dry solid for fresh blueberries (Liping 1998); 4.71g water/g of dry solid for thawed blueberries (Feng et al., 1999). Fresh blueberries had an effective diameter of $13.41 \mathrm{~mm}$ and sphericity of 0.89 , consistent with ranges reported in literature: $10.40-17.00 \mathrm{~mm}$ for diameter and $0.90-0.99$ for sphericity for fresh blueberries (Kaleta, 2011). Shi et al (2008b) report that more than $85 \%$ of fresh blueberries had diameter within $11.50-14.50 \mathrm{~mm}$. They further report that blueberry size correlates with drying rates, for example, drying rates increase with decrease in berry size, although a similar drying rate was recorded for sizes ranging between 13 to $16 \mathrm{~mm}$. Upon thawing, the effective diameter and sphericity reduced to $9.28 \mathrm{~mm}$ and 0.76 respectively. The difference in the shape and sizes of the blueberries due to shrinkage that occurred as a result of thawing was observed visually. Shrinkage is essentially due to volumetric water loss and it affects the microstructure of tissue cells (Moreira \& Sereno 2003; Allan-Wojtas, et al.,1999). Raghavan \& Silveira (2001) reported that shrinkage is linearly correlated with moisture ratio for strawberries. Dimensional characteristic of spherical particles like blueberries increases with an increase in moisture content (Kaleta, 2011). The true densities (density of a single blueberry) of fresh and frozen blueberries 
233 were 1.18 and $1.16 \mathrm{~g} / \mathrm{cm}^{3}$, respectively whereas their bulk densities were 0.35 and $0.39 \mathrm{~g} / \mathrm{cm}^{3}$, 234 respectively. After drying, the true density increased to $1.72 \mathrm{~g} / \mathrm{cm}^{3}$, while the bulk density 235 reduced to $0.20 \mathrm{~g} / \mathrm{cm}^{3}$ for fresh blueberries. This is in agreement with the work of (Martynenko, 236 2014), in which the true density was shown to increase with a decrease in moisture content and 237 bulk density was shown to decrease with a reduction in moisture content at a drying temperature 238 above $40{ }^{\circ} \mathrm{C}$ for blueberries. Total volumetric shrinkage was $88.10 \%$ as result of drying.

239 Shrinkage of food matrixes during drying has a direct impact on volume reduction, bulk density 240 and porosity of the food products (Qiu et al., 2015). Moisture loss and volumetric shrinakge data

241 showed that, on average, $69.51 \mathrm{~cm}^{3}$ of water was present in $62.75 \mathrm{~cm}^{3}$ volume space, probably 242 due to compression of water inside the blueberries. Therefore, on average, there was $9.75 \%$ 243 volumetric compression of water inside the fresh blueberry sample. Similarly, after drying of 244 frozen blueberries, the true and bulk densities decreased to $0.96 \mathrm{~g} / \mathrm{cm}^{3}$ and $0.19 \mathrm{~g} / \mathrm{cm}^{3}$ 245 respectively, the total volumetric shrinkage of $73.52 \%$ and on average $79.76 \mathrm{~cm}^{3}$ water was 246 present in only $59.70 \mathrm{~cm}^{3}$ space. Statistically, the compression of water in the thawed blueberries 247 was similar to that of the fresh ones ( $\mathrm{p}$-value>0.05).

248 Table 1

250 Drying characteristics of fresh and frozen (thawed) blueberries were determined in a TGA 251 equipment under isothermal drying at $105{ }^{\circ} \mathrm{C}$ under a dry nitrogen atmosphere. To understand 252 how the moisture ratio changes over the drying time, Fig. 2 was plotted for the two samples:

253 Fig. 2. 
254 The frozen (thawed) blueberries showed a rapid decline in moisture ratio throughout the drying 255 period when compared to the fresh ones. The fresh blueberries took about 260 min to completely 256 dry whereas the frozen blueberries took only $170 \mathrm{~min}$, about $53 \%$ less time. The rapid moisture 257 loss in the frozen blueberries could be attributed to their ruptured surface and internal cell 258 structure as reported in literature. For example, Zielinska et al., reported that frozen blueberries 259 had fractures on their surface and internal tissues, which were not present in fresh blueberries. 260 That is why the frozen blueberries take $29 \%$ less drying time than fresh blueberries (Zielinska et 261 al., 2015). Shi et al. reported a similar trend with the use of $\mathrm{NaOH}$ as a pretreatment prior to 262 drying of blueberries (Shi et al, 2008b). They reported that pretreatment with $\mathrm{NaOH}$ resulted in 263 an increase in water loss at temperatures above $80^{\circ} \mathrm{C}$ due to cracks and deformations made to 264 the fruit tissues, clearly visible under the scanning electron microscope (SEM), when compared 265 to the samples without pretreatment. To better understand how the drying rate changes with 266 moisture content of blueberries, drying characteristic curves were prepared (Fig. 3). Generally, 267 drying of agriculture products has three different periods: 1. an initial heating period, 2. a 268 constant rate period, and 3. a falling rate period (Geankoplis, 2003). The falling rate period 269 progressed in two distinct visible segments (slopes) along with an intermediate transition 270 segment. The first falling rate segment is mainly due to moisture movement controlled by 271 convective flow, which has gentler slope than the latter diffusion flow controlled drying segment 272 (Geankoplis, 2003). Current research made no mention of the observation of a constant rate 273 drying period and the drying proceeded in only heating and falling rate periods. It took about 17 $274 \min$ to reach isothermal conditions of $105^{\circ} \mathrm{C}$. Fig. 3 also clearly shows that the drying rate was 275 higher for frozen blueberries than the fresh blueberries throughout the moisture range.

276 Fig. 3. 
277 However, the drying rate declined for both samples as the drying progressed. At the start of 278 drying, moisture present closer to the fruit surface quickly evaporated, forming a dry shell 279 encasing a moist core. In this situation, the blueberries took on a core-shell structure. The dried 280 shell continuously grew over time compressing the moist core, which means moisture now had 281 to travel through the dried shell via a "diffusion-in-solid"-dominated process; therefore, the slope 282 of drying curve became less steep. Overall, liquid diffusion coefficients were also calculated for 283 the moisture range of green (fresh) to the moisture content of $15 \mathrm{~g} / 100 \mathrm{~g}$ (w.b), which is the 284 typical moisture content of commercially dried blueberries. The liquid diffusion coefficients for 285 the frozen (thawed) and fresh blueberries were found to be $8.72 \times 10^{-10} \mathrm{~m}^{2} / \mathrm{s}$ and $9.11 \times 10^{-10}$ $286 \mathrm{~m}^{2} / \mathrm{s}$, respectively, at a temperature of $105{ }^{\circ} \mathrm{C}$. The reported values of overall liquid diffusion 287 coefficients are $0.24 \times 10^{-10}, 1.44 \times 10^{-10}$ and $12.11 \times 10^{-10} \mathrm{~m}^{2} / \mathrm{s}$ at temperatures of 40,60 , and 80 $288{ }^{\circ} \mathrm{C}$, respectively for fresh blueberries using a laboratory oven dryer. Additionally, liquid 289 diffusion coefficients for steam-blanched blueberries were reported to be $0.49 \times 10^{-10}, 1.93 \times 10^{-}$

$290{ }^{10} \mathrm{~m}^{2} / \mathrm{s}$ and $12.80 \times 10^{-10} \mathrm{~m}^{2} / \mathrm{s}$ at temperatures of 40,60 , and $80{ }^{\circ} \mathrm{C}$, respectively. There appears to 291 be little difference in the values of liquid diffusion coefficients due to blanching, however, an 292 increase in temperature does have a significant positive effect. (Liping, 1998).

297 for frozen blueberries. Fresh and frozen blueberries were subjected to osmotic dehydration in a $29842 \pm 2{ }^{\circ}$ Brix sugar solution at $50{ }^{\circ} \mathrm{C}$. During osmotic dehydration, the sugar concentration was 299 continuously measured both for the blueberries and osmotic solution to determine when it 
300 became constant, as an indication of completion of the osmotic process. As osmotic dehydration

301 proceeds, the sugar concentration of blueberries tends to increase while the sugar concentration

302 of the osmotic solution tends to decrease until an equilibrium is reached between sugar and water

303 concentrations inside blueberries with those in the osmotic solution. Changes in sugar

304 concentration of fresh blueberries and frozen blueberries and their respective osmotic solutions

305 are presented in Fig. 4a and Fig. 4b.

306 Fig. 4.

307 A quick observation of these figures indicates that it took an immersion time of about 420 mins

308 for the sugar concentration to stabilize in the blueberries and the osmotic solution. In addition,

309 there was barely any change in the sugar concentration of the osmotic solution for the fresh

310 blueberries (Fig. 4a). However, the sugar concentration of the osmotic solution of frozen

311 blueberries dropped quickly while the sugar concentration of the frozen blueberries increased

312 significantly (Fig. 4b).

313 The frozen blueberries showed a steady increase in the sugar concentration from $12.50{ }^{\circ} \mathrm{Brix}$ to

$31432.90{ }^{\circ}$ Brix in $420 \mathrm{~min}$ (Fig. 5). In contrast, the fresh blueberries showed a small increment of

315 change from $10.20^{\circ}$ Brix to $13.40{ }^{\circ}$ Brix in 200 min and remained at this level even after long

316 hours of immersion (about $10 \mathrm{~h}$ ). The difference in the increase of sugar concentrations between

317 the fresh and frozen blueberries may be explained by the fractured fruit skin and inner cell

318 membranes of the frozen product, as a result of freezing (Zielinska et al., 2015). Fractured frozen

319 fruit skin and internal cells facilitate two-way diffusion and convective flow (facilitated by

320 mechanical shaking). In the frozen blueberries, ruptured fruit skin does not create an osmotic

321 barrier for sugar flow from the solution to inside the fruit. 
322

323

324

325

326

327

328

329

330

331

332

333

334

335

336

337

338

339

340

341

342

343

344

Fig. 5.

On the other hand, the fresh blueberries have a strong osmotic barrier due to their continuous skin, which does not permit sugar to flow easily inside of the fruit. Additionally, total solid gain and water loss of blueberries after osmotic dehydration were also calculated related to fruit weight and moisture content before and after the osmotic process (Table 2). It is shown that, three times as much solid was infused in frozen blueberries $(23 \%)$ compared to the fresh fruit at the end of the osmotic process, while simultaneously 3.9 times as much water was lost from the frozen berries $(181 \%)$. (Kucner et al., 2013) reported a water loss of $0.66 \mathrm{~g}$ of water per $\mathrm{g}$ of initial dry solid and a solid gain of $0.14 \mathrm{~g}$ dry solid per $\mathrm{g}$ of initial dry solid for osmotic dehydration of frozen blueberries without pretreatment (at $50{ }^{\circ} \mathrm{C}, 65^{\circ}$ Brix sucrose solution, fruit to syrup ratio of 1 to 4 for $240 \mathrm{~min}$ ) (Kucner et al. 2013). It has been generally reported that more water is lost than solid gained during the osmotic dehydration of fruits and vegetables (Azarpazhooh E. and Ramaswamy, 2010). Fruit skin acts as a barrier to the infusion of larger molecular weight sugar like sucrose. Moreover, the simultaneous leaching of the fruit acid into the osmotic solution causes accelerated hydrolysis of sucrose to glucose and fructose and leads to high water loss (Azarpazhooh E. and Ramaswamy, 2010). Another observation illustrated in Table 2 is that frozen berries show a higher yield than fresh ones. A higher sugar gain is a proof of higher yield (Shi et al., 2009).

\section{Table 2}

Osmotically dehydrated fresh and frozen blueberries were further air dried in a fruit dehydrator. The fruit dehydrator was set for air temperature of $74{ }^{\circ} \mathrm{C}$, the highest rating of the dehydrator model. During the air-drying, the ambient conditions were $21.10 \pm 2.00{ }^{\circ} \mathrm{C}$ and relative humidity of $44.00 \pm 5.00 \%$. Moisture content and water activity $\left(\mathrm{a}_{\mathrm{w}}\right)$ of the samples being dried 
345 were continuously monitored at preset intervals of $2 \mathrm{~h}$. Both the frozen and fresh blueberries

346 showed a steady decline in water activity with drying time. Changes in water activity and

347 moisture content during air-drying are shown in Fig. 6. However, for the first 600 min, the $a_{w}$

348 and moisture content of the osmotically dried frozen blueberries showed more rapid decline than

349 the osmotically dried fresh blueberries. Another observation shown in Fig. 6 is that the

350 osmotically dried frozen blueberries reached an $a_{w}$ value of 0.4 in $420 \mathrm{~min}$, which occurred at the

351 moisture content of $0.05 \mathrm{~g}$ of water per $\mathrm{g}$ of dry solid. On the other hand, osmotically dried fresh

352 blueberries took $600 \mathrm{~min}$ to attain the same water activity at the same moisture content of $0.05 \mathrm{~g}$

353 of water per $\mathrm{g}$ of dry solid. A closer look at the chart shows that relative to the initial moisture

354 content, osmotically dried frozen berries showed a higher moisture loss to reach the target water

355 activity than the osmotically dried fresh blueberries. This was corroborated by the work of (Shi

356 et al., 2008a). This study observed that reduced drying times of sugar-infused blueberries

357 compared to fresh ones can be attributed to two possible reasons: (1) low initial moisture content

358 of the sugar infused blueberries (2) impediments posed by the infused sugar. Both effects result

359 in lowering the drying rate and thus allowing osmotically dried blueberries to be dried at higher

360 moisture to achieve the same water activity as dried fresh ones.

361 Fig. 6.

362

3.4 Comparing Sugar and Apple Juice-Based Osmotic Solutions during Osmotic Dehydration of

Frozen Blueberries and Subsequent Air Drying

365 The frozen blueberries were subjected to osmotic dehydration in an apple juice-based osmotic 366 solution $\left(42.00 \pm 2.00{ }^{\circ}\right.$ Brix) and in a sugar-based osmotic solution $\left(42.00 \pm 2.00{ }^{\circ}\right.$ Brix $)$ at $50{ }^{\circ} \mathrm{C}$. 
367 Fig. 7 ( $a$ and $b$ ) shows changes in the blueberry and osmotic solution sugar concentrations as the 368 osmotic dehydration progressed in two situations. In both conditions, the sugar concentration in 369 the fruit as well as in the solutions stabilized before $400 \mathrm{~min}$ incubation period. In fact, the 370 osmotic process was completed in just 300 min when an apple juice-based solution was used.

$371 \quad$ Fig. 7.

372 Therefore, $400 \mathrm{~min}$ is sufficient to complete osmotic process for frozen blueberries in a $37342.00 \pm 2.00{ }^{\circ}$ Brix osmotic solution at $50{ }^{\circ} \mathrm{C}$, irrespective of solution type. The results of the 374 osmotic dehydration studies indicate that the frozen blueberry sugar concentration increased 375 from $12.50{ }^{\circ}$ Brix to $30.30{ }^{\circ}$ Brix when the apple juice-based osmotic solution was used, and to $37632.90{ }^{\circ}$ Brix when the sugar-based osmotic solution was used. There was no statistical difference 377 in the final sugar concentration of the blueberry samples in the two situations ( $\mathrm{p}$-value $>0.05$ ) 378 (Fig. 8). While the sugar concentration of the fruit increased, the concentration of sugar in both 379 solutions decreased from an average value of $42.26^{\circ}$ Brix to $38.25^{\circ}$ Brix.

$380 \quad$ Fig. 8.

381 It is observed in Fig. 8 that the sugar concentration of frozen blueberries increased in a 382 nonlinear manner with time. The frozen berries pretreated with apple-based osmotic solution, 383 initially showed a lower sugar gain (first $120 \mathrm{~min}$ ), followed by a higher sugar gain over the next 384240 min than that for the fruit pretreated with sugar-based osmotic solution. It has been reported 385 that most water loss and sugar gain are achieved at the first 1hour of the osmotic process 386 (Azarpazhooh E. and Ramaswamy, 2010). In another study, the highest water loss and solid gain 387 were achieved at a contact time after 180 min (Kucner et al., 2013). Additionally, solid gain and 388 water loss in blueberries during osmotic dehydration are presented in Table 3 . The type of 
389 osmotic solution used did not create a significant difference in water loss. The water loses were

$390 \quad 1.91$ and $1.81 \mathrm{~g}$ of water per $\mathrm{g}$ of dry solids for apple juice-based and sugar- based solutions, 391 respectively.

392 Table 3

393 However, type of osmotic solution used had a significant effect on solid gains. The use of apple 394 juice-based sugar solution showed solid gains of $0.53 \mathrm{~g}$ dry solid per $\mathrm{g}$ of initial dry solid, which 395 was higher than that shown by the sugar-based solution $(0.23 \mathrm{~g}$ dry solid per $\mathrm{g}$ of initial dry 396 solid). Another observation from the table is that frozen berries immersed in an apple juice 397 solution result in a higher yield $(79.31 \%)$ than those immersed in a sugar-based solution (76.33 $398 \%)$. However, the difference was statistically insignificant at ( $\mathrm{p}$-value $=0.09)$. The changes in 399 water activity of osmotically dried frozen blueberries using apple juice and sugar-based osmotic 400 solution, during air-drying in a fruit dehydrator set at $74{ }^{\circ} \mathrm{C}$, are presented in Fig. 9. The data 401 shows that both samples demonstrated a steady decline in water activity with drying time. 402 However, frozen fruit immersed with the sugar-based osmotic solution showed a much more 403 rapid decline for the first $600 \mathrm{~min}$. Moreover, it took a drying time of 420 min to reach a water 404 activity of 0.4 at a moisture content of $0.05 \mathrm{~g}$ of water per $\mathrm{g}$ of dry solids for the frozen berries 405 immersed in the sugar-based osmotic solution. To reach the same water activity level, it took 480 $406 \mathrm{~min}$ at a moisture content of $0.09 \mathrm{~g}$ of water per $\mathrm{g}$ of dry solids for the frozen berries immersed in 407 the apple juice osmotic solution. The difference in drying time could be attributed to a higher 408 solid gain by the latter sample which slows down the drying rate(Shi et al., 2008a).

409 Fig. 9. 
This research establishes that the effect of freezing the fruit prior to hot air drying resulted in a significant reduction in drying time (53\% reduction) to reach $0.18 \mathrm{~g}$ water $/ \mathrm{g}$ of dry solid, compared with the similarly dried fresh blueberries. Fresh and frozen berries followed the conventional drying characteristic curves typical of fruits, where only falling rate period but no constant rate regime exist. The drying behavior and a higher drying rate of the frozen berries were facilitated by ruptures in the berries' waxy skin, caused by freezing.

Moreover, the use of osmotic dehydration prior to drying significantly reduces the moisture content of the frozen fruit by about $30 \%$ (from $5.70-3.97 \mathrm{~g}$ of water/g of dry solid) and fresh blueberries by $15 \%$ (5.16 - 4.3997g of water/g of dry solid). Use of an apple juice-based osmotic solution led to a significant higher solid gains in the frozen blueberries than those from a sugar-based osmotic solution. The sugar concentration of frozen blueberries increased from $12.50{ }^{\circ}$ Brix to $30.30{ }^{\circ}$ Brix when the apple juice-based osmotic solution was used and to 32.90 ${ }^{\circ}$ Brix when the sugar-based osmotic solution was used. On the subsequent hot air drying, the frozen berries treated with sugar-based solution showed a shorter drying time of 420 min than those treated with apple juice-based solution $(480 \mathrm{~min}$ ) to achieve a water activity of 0.4 . Therefore, fruit juice concentrates, for example apple juice, may be used as an osmotic solution as a substitute for granular sugar without compromising final yield of the dried blueberries.

Acknowledgements- This work is partially supported by the USDA National Institute of Food and Agriculture, McIntire Stennis project 0222863 and 1007044. In addition, support was also provided by West Virginia University (WVU) Public Service Grant Award\# P-14-006, WVU ADVANCE/Sponsorship Program, and WVU Extension Service- Families and Health Programs. Authors also acknowledge Dr. John W. Zondlo, Professor, Department of Chemical Engineering, West Virginia University for providing technical review of this manuscript. Similarly, authors 
434 acknowledge Winifred W. McGee, Senior Extension Educator, Agricultural Entrepreneurship, 435 Penn State Extension for proofreading the revised manuscript for grammatical and punctuation 436 errors.

437 References

438 Allan-Wojtas, P., Goff, H., Stark, R., \& Carbyn, S. (1999). The effect of freezing method and 439 440 frozen storage conditions on the microstructure of wild blueberries as observed by cold-stage scanning electron microscopy. Scanning, 21(5), 334-347.

American Association of Cereal Chemist. (2000). Approved Methods of the AACC (10th ed.) (pp. Method 44-15A). St. Paul, Minn: The Association

American Society for Testing Materials. (2009). Standard Test Method for Bulk Density ("Unit Weight”) and Voids in Aggregate; ASTM C29/C29M-09. West Conshohocken, Pa.

American Society for Testing Materials. (2015). Standard Test Methods for Proximate Analysis of Coal and Coke by Macro Thermogravimetric Analysis; ASTM D7582-15.West

Azarpazhooh E. and Ramaswamy, H. S. (Ed.) (2010). Osmotic Dehydration (Vol. 1). Singapore.

Chen, D., Zheng, Y., \& Zhu, X. (2012). Determination of effective moisture diffusivity and drying kinetics for poplar sawdust by thermogravimetric analysis under isothermal condition. Bioresource technology, 107, 451-455.

452 Feng, H. A. O., Tang, J., Mattinson, D. S., \& Fellman, J. K. (1999). Microwave and spouted bed 453 drying of frozen blueberries: the effect of drying and pretreatment methods on physical 454 455 properties and retention of flavor volatiles. Journal of Food Processing and Preservation, 23(6), 463-479. doi:10.1111/j.1745-4549.1999.tb00398.x 
456 Geankoplis, C. (2003). Transport processes and separation process principles (includes unit

457

458

459

460

461

462

463

464

465

466

467

468

469

470

471

472

473

474

475

476

477

478 operations): Prentice Hall Press.

Jain, R. K. \& Bal, S. (1997). Physical properties of pearl millet. Journal of Agricultural Engineering Research (66).

Jimenez-Garcia, S. N., Guevara-Gonzalez, R. G., Miranda-Lopez, R., Feregrino-Perez, A. A., Torres-Pacheco, I., \& Vazquez-Cruz, M. A. (2013). Functional properties and quality characteristics of bioactive compounds in berries: Biochemistry, biotechnology, and genomics. Food Research International, 54(1), 1195-1207. doi:http://dx.doi.org/10.1016/j.foodres.2012.11.004

Kaleta, A. \& Gornicki, K. (2011). Databases on physical properties of plants and agricultural products. In J. Gliński, J. Horabik \& J. Lipiec (Eds.), Encyclopedia of Agrophysics (pp. 189-194). Dordrecht: Springer Netherlands

Konopacka, D., Jesionkowska, K., Klewicki, R., \& Bonazzi, C. (2009). The effect of different osmotic agents on the sensory perception of osmo-treated dried fruit. The Journal of Horticultural Science and Biotechnology, 84(6), 80-84.

Konopacka, D., Jesionkowska, K., Mieszczakowska, M., \& Płocharski, W. (2008). The usefulness of natural concentrated fruit juice as osmotic agent for osmo-dehydrated dried fruit production. Journal of Fruit and Ornamental Plant Research, 16, 275-284.

Kucner, A., Klewicki, R., \& Sójka, M. (2013). The influence of selected osmotic dehydration and pretreatment parameters on dry matter and polyphenol content in highbush blueberry (Vaccinium corymbosum L.) fruits. Food and Bioprocess Technology, 6(8), 2031-2047.

Liping, Y. (1998). Osmotic-Air Dehydration of Cherries and Blueberries. Msc Thesis. Department of Biosystem Engineering,. University of Manitoba, Winnipeg, Manitoba. 
Retrived

from: http://www.coolectionscanada.gc.ca./obj/s4/f2/dsk2/tape17/PQDD_0003/MQ32286.pdf

Martineau, L. C., Couture, A., Spoor, D., Benhaddou-Andaloussi, A., Harris, C., Meddah, B., . . . Haddad, P. S. (2006). Anti-diabetic properties of the Canadian lowbush blueberry Vaccinium angustifolium Ait. Phytomedicine, 13(9-10), 612-623. doi:http://dx.doi.org/10.1016/j.phymed.2006.08.005

Martynenko, A. (2014). True, particle, and bulk density of shrinkable biomaterials: evaluation from drying experiments. Drying Technology, 32(11), 1319-1325. doi:10.1080/07373937.2014.894522

Mohsenin, N. N. (1986). Physical properties of plant and animal materials : Structure, physical, characteristics and mechanical properties. Amsterdam:: Gordon and Breach Science Publishers.

Moreira, R., \& Sereno, A. M. (2003). Evaluation of mass transfer coefficients and volumetric shrinkage during osmotic dehydration of apple using sucrose solutions in static and nonstatic conditions. Journal of Food Engineering, 57(1), 25-31. doi:http://dx.doi.org/10.1016/S0260-8774(02)00217-0

Nile, S. H., \& Park, S. W. (2014). Edible berries: bioactive components and their effect on human health. Nutrition, 30(2), 134-144. doi:http://dx.doi.org/10.1016/j.nut.2013.04.007

Nsonzi, F., \& Ramaswamy, H. S. (1998). Osmotic dehydration kinetics of blueberries. Drying Technology, 16(3-5), 725-741. doi:10.1080/07373939808917432

Omobuwajo, T. O., Akande, E. A. \& Sanni, L. A. (1999). Selected physical, mechanical and aerodynamic properties of african breadfruit (treculia africana) seeds. Journal of Food Engineering, 40(4), 241-244. 
502 Qiu, J., Khalloufi, S., Martynenko, A., Van Dalen, G., Schutyser, M., \& Almeida-Rivera, C.

503

504

505

506

507

508

509

510

511

512

513

514

515

516

517

518

519

520

521

522

523

(2015). Porosity, Bulk Density, and Volume Reduction During Drying: Review of Measurement Methods and Coefficient Determinations. Drying Technology, 33(14), 1681-1699.

Raghavan, G., \& Silveira, A. (2001). Shrinkage characteristics of strawberries osmotically dehydrated in combination with microwave drying. Drying Technology, 19(2), 405-414.

Shi, J., Pan, Z., McHugh, T. H., \& Hirschberg, E. (2009). Effect of infusion method and parameters on solid gain in blueberries. Food and Bioprocess Technology, 2(3), 271-278. doi:10.1007/s11947-008-0116-4

Shi, J., Pan, Z., McHugh, T. H., Wood, D., Hirschberg, E., \& Olson, D. (2008a). Drying and quality characteristics of fresh and sugar-infused blueberries dried with infrared radiation heating. LWT - Food Science and Technology, 41(10), 1962-1972.

doi: http://dx.doi.org/10.1016/j.lwt.2008.01.003

Shi, J., Pan, Z., McHugh, T. H., Wood, D., Zhu, Y., Avena-Bustillos, R. J., \& Hirschberg, E. (2008b). Effect of berry size and sodium hydroxide pretreatment on the drying characteristics of blueberries under infrared radiation heating. Journal of Food Science, 73(6), E259-E265. doi: 10.1111/j.1750-3841.2008.00816.x

United States Department of Agriculture (USDA). (2015). National statistics for blueberries. Retrived from: http://www.nass.usda.gov/Statistics_by_Subject/index.php

Vega-Gálvez, A., Lara, E., Flores, V., Di Scala, K., \& Lemus-Mondaca, R. (2012). Effect of selected pretreatments on convective drying process of blueberries (var. O'neil). Food and Bioprocess Technology, 5(7), 2797-2804. doi:10.1007/s11947-011-0656-X 
524 Vega-Gálvez, A., Lemus-Mondaca, R., Tello-Ireland, C., Miranda, M., \& Yagnam, F. (2009).

525 Kinetic Study of Convective Drying of Blueberry Variety O neil (Vaccinium 526 corymbosum L.). Chilean journal of agricultural research, 69(2), 171-178.

527 Yadav, A. K., \& Singh, S. V. (2014). Osmotic dehydration of fruits and vegetables: a review. $528 \quad$ Journal of Food Science and Technology, 51(9), 1654-1673. doi:10.1007/s13197-012$529 \quad 0659-2$

530 Zielinska, M., Sadowski, P., \& Błaszczak, W. (2015). Freezing/thawing and microwave-assisted drying of blueberries (Vaccinium corymbosum L.). LWT - Food Science and Technology, 62(1, Part 2), 555-563. doi:http://dx.doi.org/10.1016/j.1wt.2014.08.002 


\section{List of Tables}

1- Table 1. Physical characteristics, mean (standard deviation) of fresh and frozen (thawed) blueberries.

2- Table 2. Average moisture content, initial and final sugar concentration of fresh and frozen blueberries and solutions, solid gain and water loss from fruit, osmotic duration and yields during osmotic dehydration at $50^{\circ} \mathrm{C}$.

3- Table 3. Average moisture content, initial and final sugar concentration of frozen blueberries and osmotic solutions (apple juice-based and sugar based), solid gain in fruit and water loss during osmotic dehydration at $50^{\circ} \mathrm{C}$. 


\section{Table1}

Physical characteristics, mean (standard deviation) of fresh and frozen (thawed) blueberries.

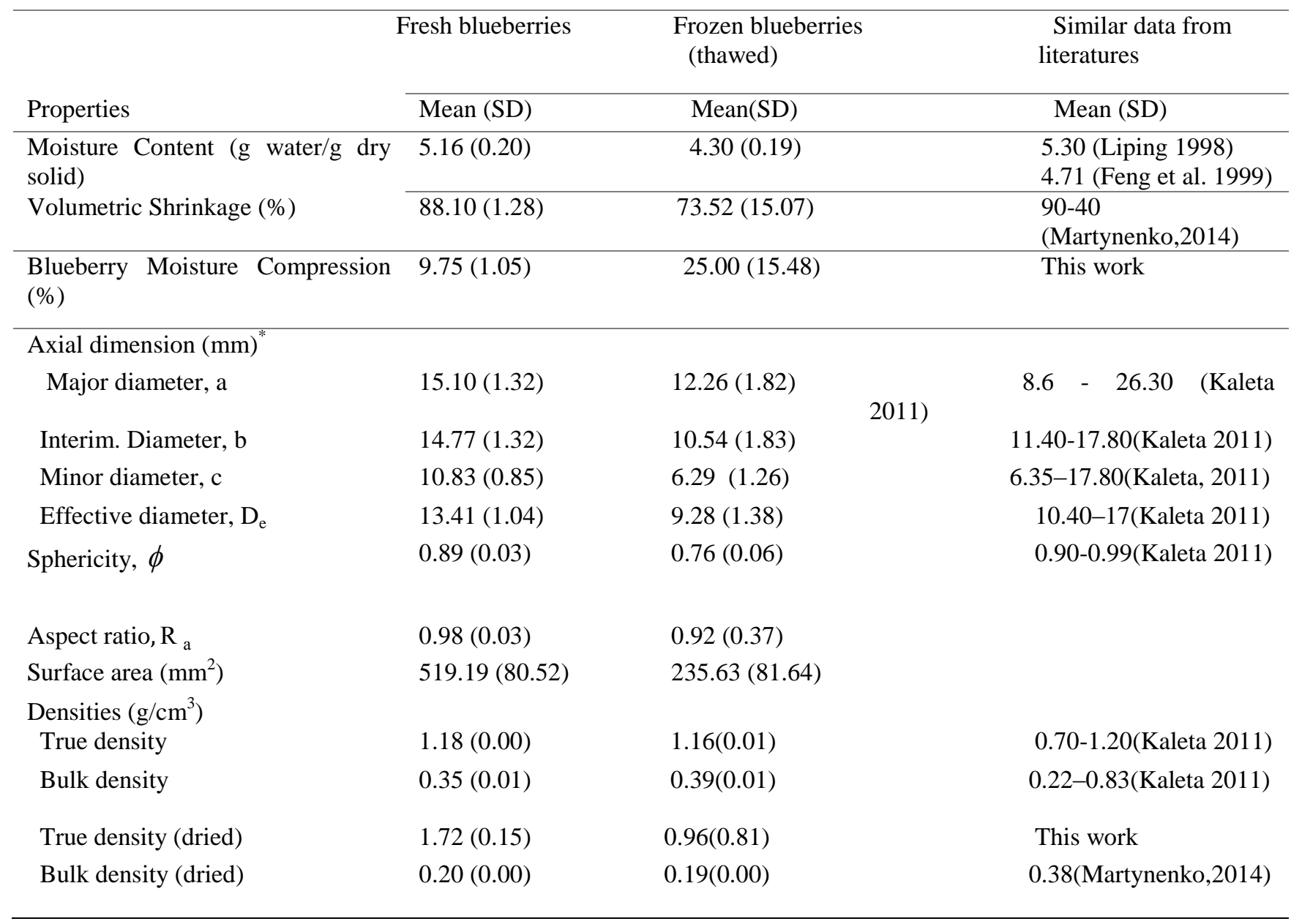

$*$ Values are averages of determinations for 100 blueberries. 


\section{Table 2}

Average moisture content, initial and final sugar concentration of fresh and frozen blueberries and solutions, solid gain and water loss from fruit, osmotic duration and yields during osmotic dehydration at $50^{\circ} \mathrm{C}$.

\begin{tabular}{|c|c|c|c|c|c|c|c|c|c|c|}
\hline \multirow[t]{2}{*}{ Fruit Type } & \multicolumn{2}{|c|}{$\begin{array}{l}\text { Moisture Content } \\
\text { (g/g of dry solid) }\end{array}$} & \multicolumn{2}{|c|}{$\begin{array}{c}\text { Solution Sugar } \\
\text { Concentration } \\
\left({ }^{\circ} \text { Brix }\right)\end{array}$} & \multicolumn{2}{|c|}{$\begin{array}{c}\text { Fruit Sugar } \\
\text { Concentration } \\
\left({ }^{\circ} \text { Brix }\right)\end{array}$} & \multirow[t]{2}{*}{$\begin{array}{c}\text { Solid Gain } \\
\text { (g/g of dry solid) }\end{array}$} & \multirow[t]{2}{*}{$\begin{array}{c}\text { Water Loss } \\
\text { (g/g of dry solid) }\end{array}$} & \multirow[t]{2}{*}{$\begin{array}{l}\text { OD duration } \\
\text { (min) }\end{array}$} & \multirow[t]{2}{*}{$\begin{array}{c}\text { Yield of OD } \\
\text { Fruit (\%) }\end{array}$} \\
\hline & Initial & Final & Initial & Final & Initial & Final & & & & \\
\hline Fresh & 5.16 & 4.39 & 43.80 & 44.60 & 10.20 & 13.40 & 0.07 & 0.47 & 600 & 93.51 \\
\hline Blueberries & $(0.20)$ & $(0.69)$ & & & & & $(0.02)$ & $(0.08)$ & & $(1.51)$ \\
\hline Frozen & 5.70 & 3.97 & 41.80 & 38.60 & 12.50 & 32.90 & 0.23 & 1.81 & 420 & 76.33 \\
\hline Blueberries & $(0.57)$ & $(0.14)$ & & & & & $(0.02)$ & $(0.04)$ & & $(0.77)$ \\
\hline
\end{tabular}

Standard deviation in parentheses. Replicate of two results 


\section{Table 3}

Average moisture content, initial and final sugar concentration of frozen blueberries and osmotic solutions (apple juice-based and sugar based), and solid gain in fruit and water loss during osmotic dehydration at $50^{\circ} \mathrm{C}$.

\begin{tabular}{|c|c|c|c|c|c|c|c|c|c|}
\hline \multirow[t]{2}{*}{$\begin{array}{c}\text { Osmotic solution } \\
\text { Type }\end{array}$} & \multicolumn{2}{|c|}{$\begin{array}{l}\text { Moisture Content } \\
\text { (g/g of dry solid) }\end{array}$} & \multicolumn{2}{|c|}{$\begin{array}{c}\text { Osmotic Solution } \\
\text { Concertation } \\
\left({ }^{\circ} \text { Brix }\right) \\
\end{array}$} & \multicolumn{2}{|c|}{$\begin{array}{c}\text { Frozen Blueberry } \\
\text { Sugar Concertation } \\
\left({ }^{\circ} \text { Brix }\right) \\
\end{array}$} & \multirow[t]{2}{*}{$\begin{array}{c}\text { Solid Gain } \\
\text { (g/g of dry solid) }\end{array}$} & \multirow[t]{2}{*}{$\begin{array}{c}\text { Water Loss } \\
\text { (g/g of dry solid) }\end{array}$} & \multirow[t]{2}{*}{$\begin{array}{l}\text { Yield of OD Fruit } \\
\qquad(\%)\end{array}$} \\
\hline & Initial & Final & Initial & Final & Initial & Final & & & \\
\hline Apple-Juice-Based & $5.70(0.57)$ & $2.99(0.44)$ & 42.70 & 37.90 & 13.40 & 30.30 & $0.53(0.01)$ & $1.91(0.01)$ & $79.31(0.21)$ \\
\hline \multicolumn{10}{|l|}{ Solution } \\
\hline Sugar-based & $5.70(0.57)$ & $3.97(0.14)$ & 41.80 & 38.60 & 12.50 & 32.90 & $0.23(0.02)$ & $1.81(0.04)$ & $76.33(0.77)$ \\
\hline Osmotic Solution & & & & & & & & & \\
\hline
\end{tabular}

Standard deviation in parentheses. Replicate of two results 


\section{List of Figures}

1- Fig. 1. Schematic diagram of a typical blueberry showing the axial dimensions a (x-axis), b (y-axis), and c (z-axis).

2- Fig. 2. Relative moisture (moisture ratio) over the drying period performed at isothermal temperature of $105^{\circ} \mathrm{C}$ in a thermogravimetric analyzer in dry nitrogen for fresh and frozen (thawed) blueberries.

3- Fig. 3. Relationship between drying rate ( $\mathrm{g}$ of water evaporated per gr of drying fruit per minute) and mean moisture content of fresh and frozen (thawed) blueberries during drying under isothermal temperature of $105^{\circ} \mathrm{C}$ in the thermogravimetric analyzer under dry nitrogen.

4- Fig. 4. Variation of sugar concentrations over time for (a) fresh blueberries and its sugarbased osmotic solution and (b) frozen blueberries and its osmotic solution during osmotic dehydration performed at $50^{\circ} \mathrm{C}$.

5- Fig. 5. Increase in sugar concentrations for fresh and frozen blueberries during their osmotic dehydration with an osmotic solution at $50{ }^{\circ} \mathrm{C}$.

6- Figure 6. Decrease in water activity and moisture content (MC) during air-drying of osmotically dehydrated fresh and frozen blueberries in a fruit dehydrator at $74{ }^{\circ} \mathrm{C}$.

7- Fig. 7. Variation of sugar concentrations over time for (a) frozen blueberries and its sugar-based osmotic solution and (b) frozen blueberries and its apple juice-based osmotic solution during osmotic dehydration performed at $50{ }^{\circ} \mathrm{C}$.

8- Fig. 8. Sugar gained over immersion time for frozen blueberries in (1) sugar and (2) apple juice concentrate osmotic solution.

9- Fig. 9. Decrease in water activity of osmotically dehydrated frozen blueberries using sugar-based and apple juice-based osmotic solutions in a fruit dehydrator at $74{ }^{\circ} \mathrm{C}$ 


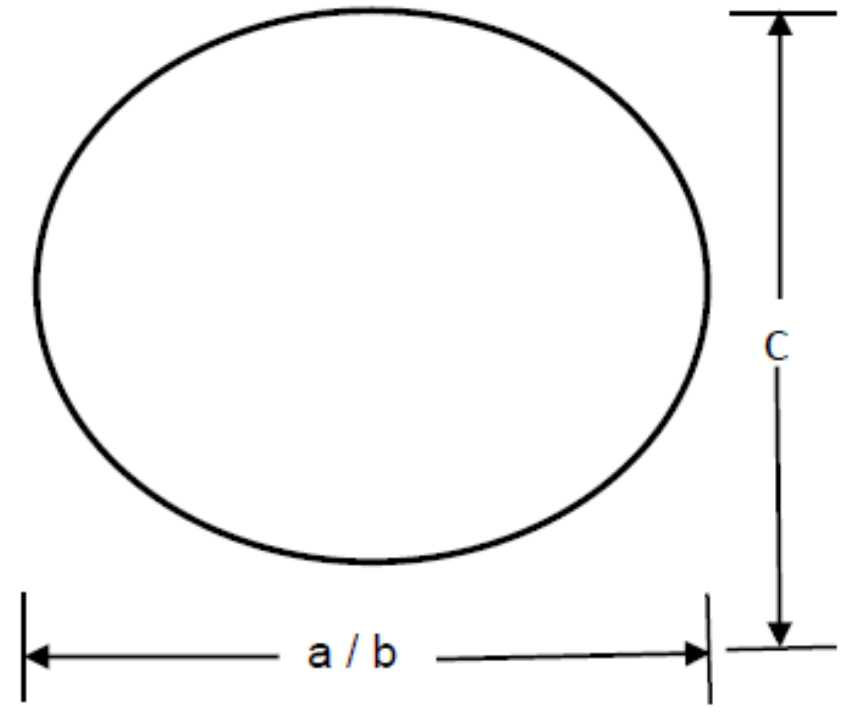

Fig. 1. Schematic diagram of a typical blueberry showing the axial dimensions a (x-axis), b (yaxis), and c (z-axis)

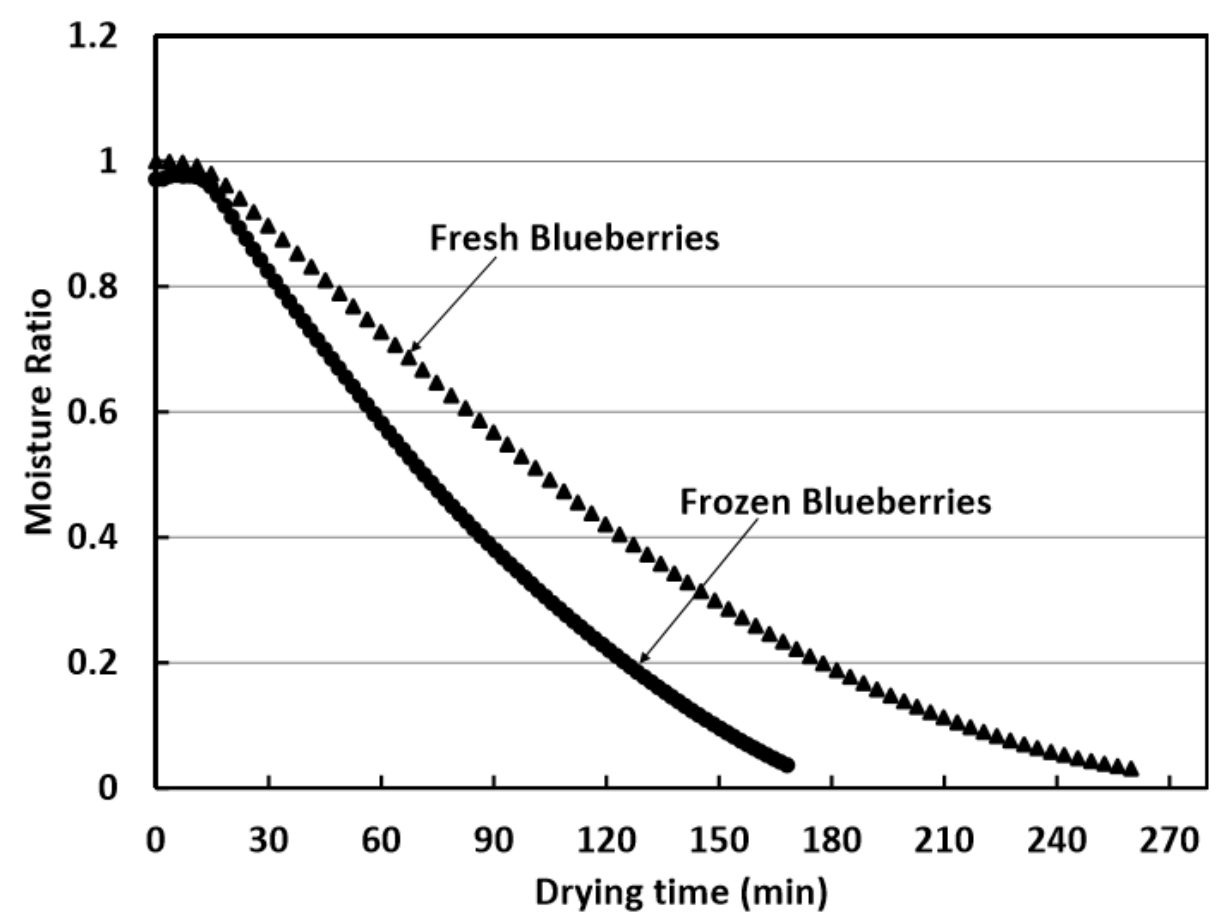

Fig. 2. Relative moisture (moisture ratio) over the drying period performed at isothermal temperature of $105^{\circ} \mathrm{C}$ in a thermogravimetric analyzer in dry nitrogen for fresh and frozen (thawed) blueberries 


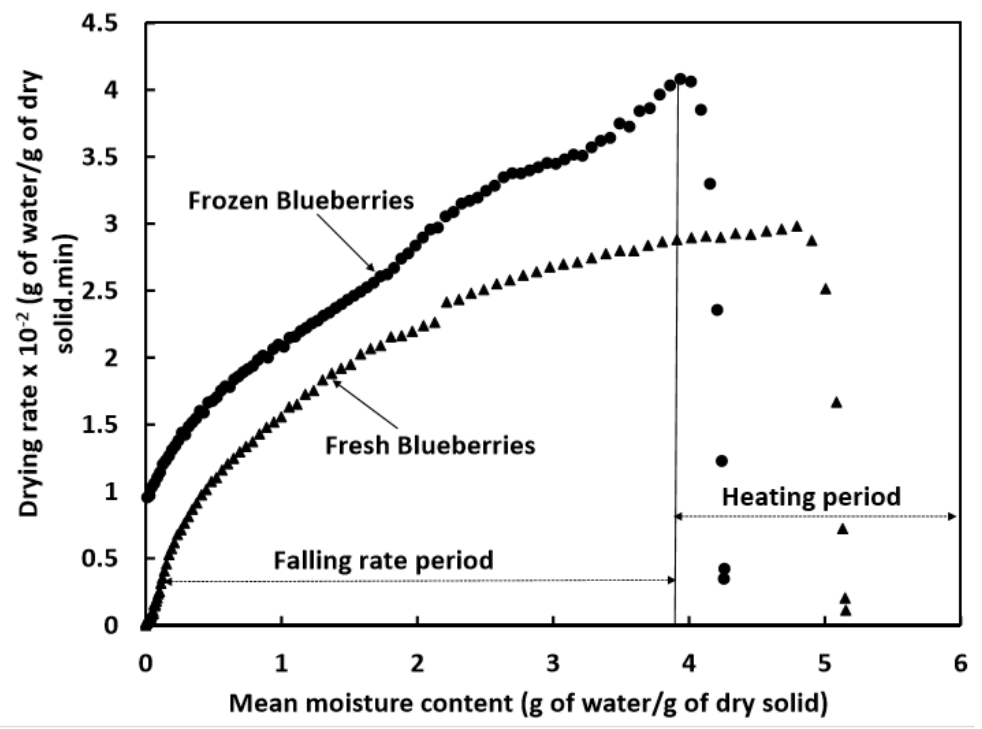

Fig. 3. Relationship between drying rate ( $g$ of water evaporated per gr of drying fruit per minute) and mean moisture content of fresh and frozen (thawed) blueberries during drying under isothermal temperature of $105^{\circ} \mathrm{C}$ in the thermogravimetric analyzer under dry nitrogen

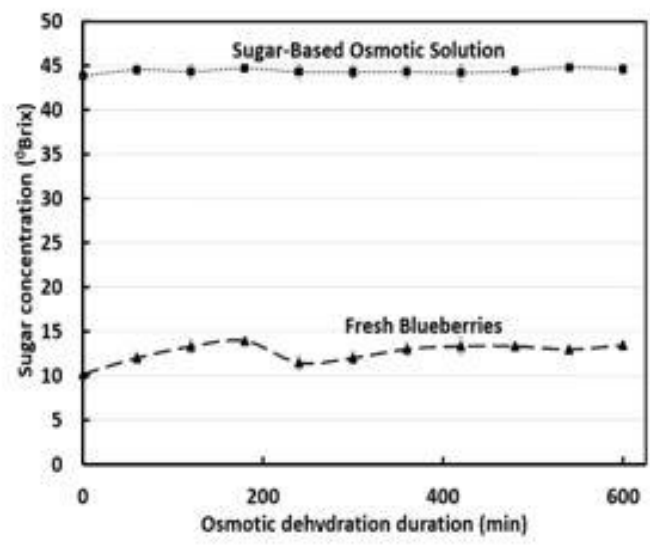

a

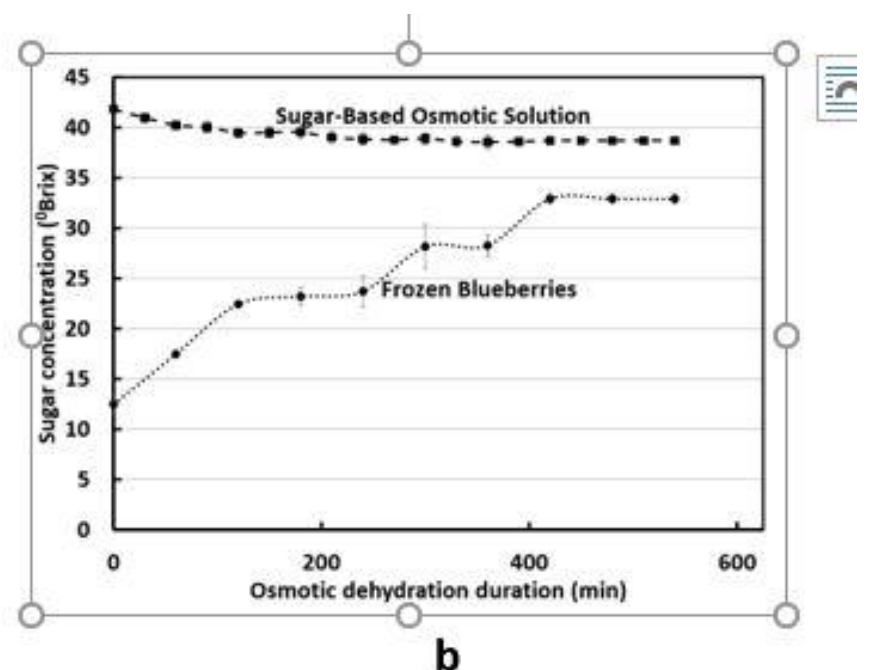

b

Fig.4. Variation of sugar concentrations over time for (a) fresh blueberries and its sugar-based osmotic solution and (b) frozen blueberries and its osmotic solution during osmotic dehydration performed at $50{ }^{\circ} \mathrm{C}$ 


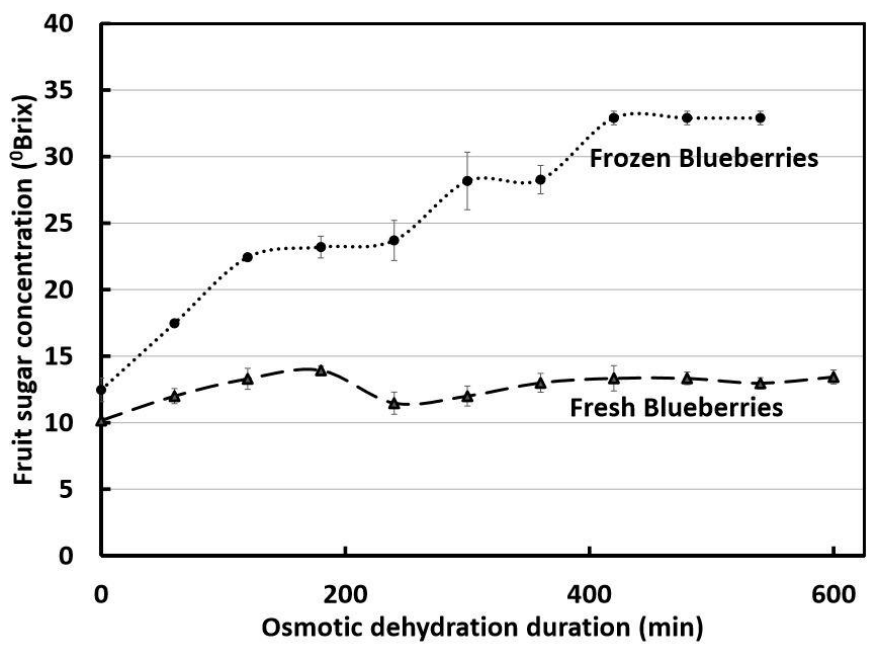

Fig. 5. Increase in sugar concentrations for fresh and frozen blueberries during their osmotic dehydration with an osmotic solution at $50{ }^{\circ} \mathrm{C}$

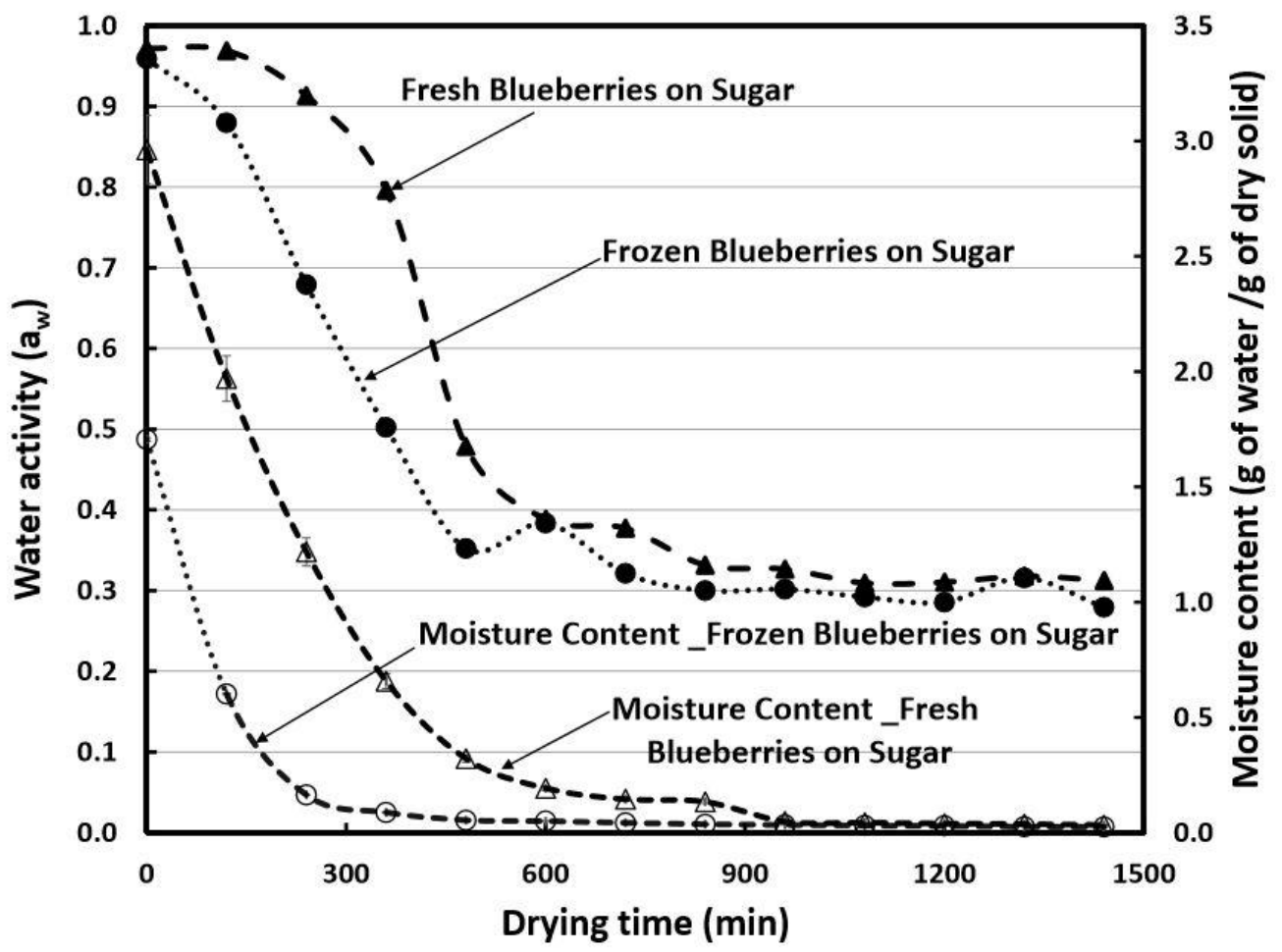

Fig. 6. Decrease in water activity and moisture content (MC) during air-drying of osmotically dehydrated fresh and frozen blueberries in a fruit dehydrator at $74{ }^{\circ} \mathrm{C}$ 


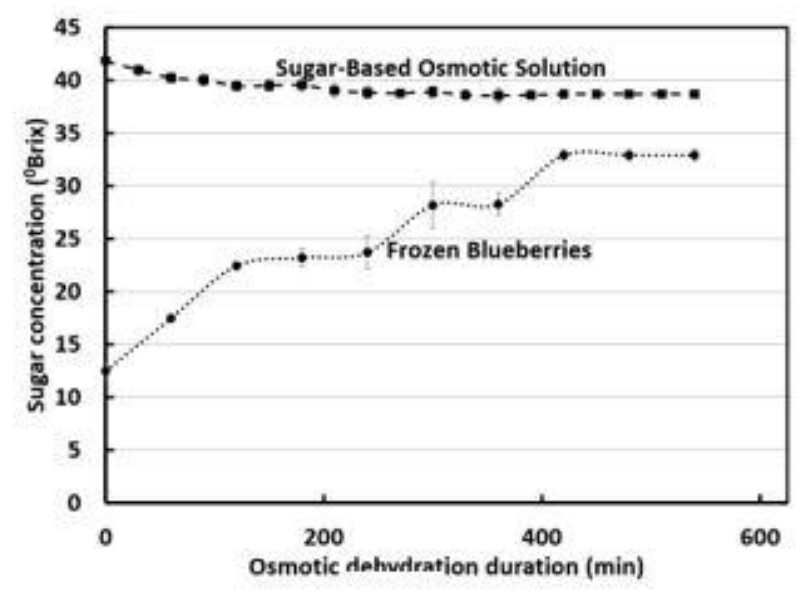

a

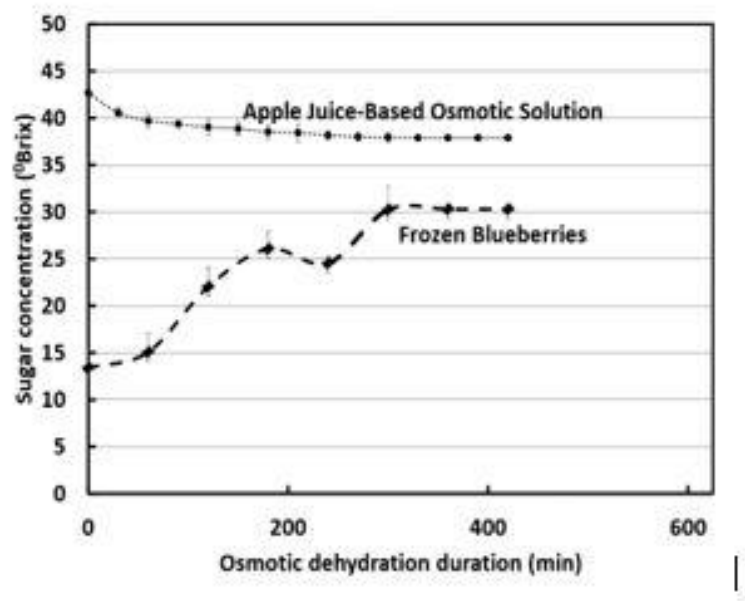

b

Fig. 7. Variation of sugar concentrations over time for (a) frozen blueberries and its sugar-based osmotic solution and (b) frozen blueberries and its apple juice-based osmotic solution during osmotic dehydration performed at $50{ }^{\circ} \mathrm{C}$

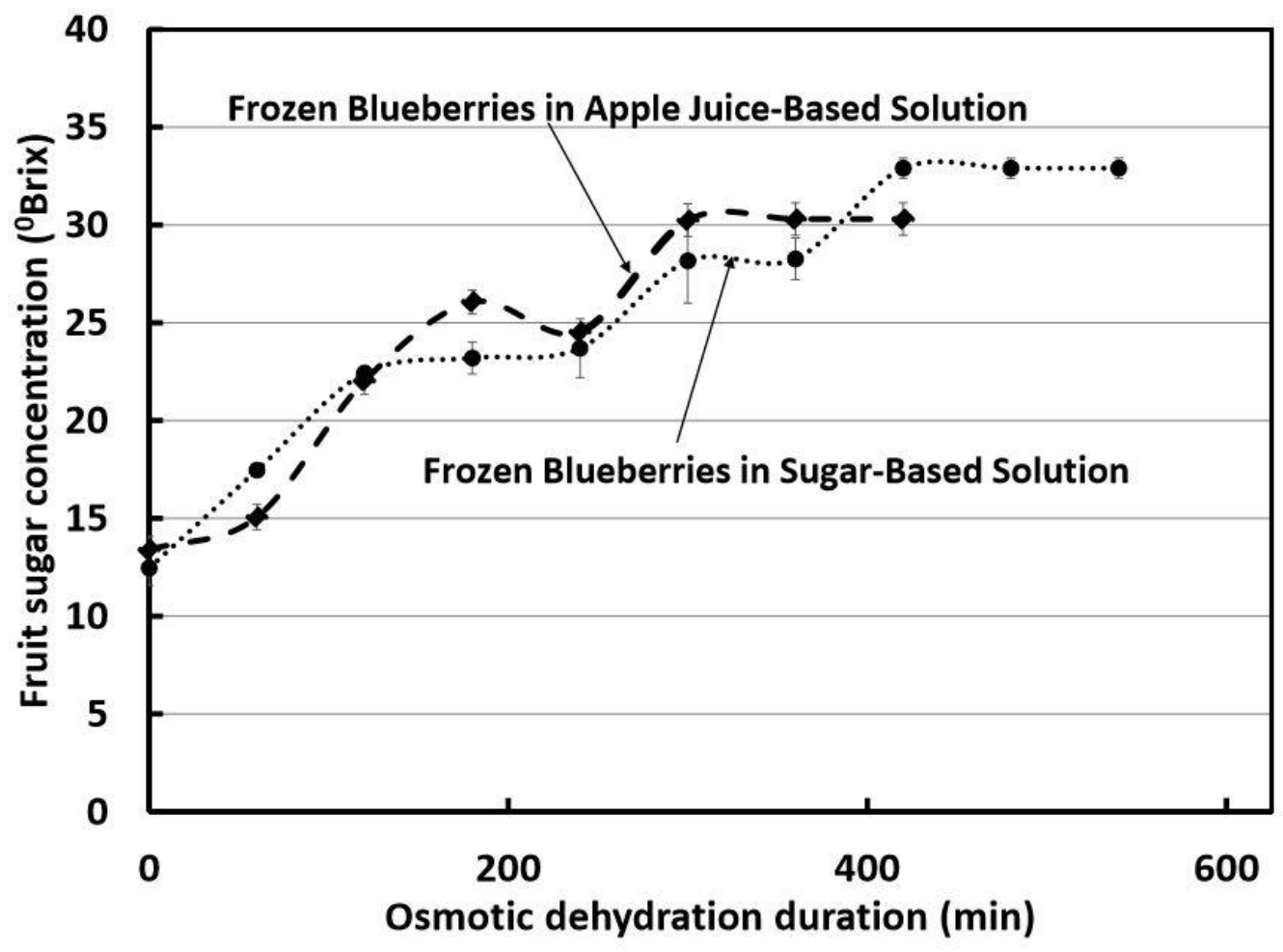

Fig. 8. Sugar gained over immersion time for frozen blueberries in (1) sugar and (2) apple juice concentrate osmotic solution 


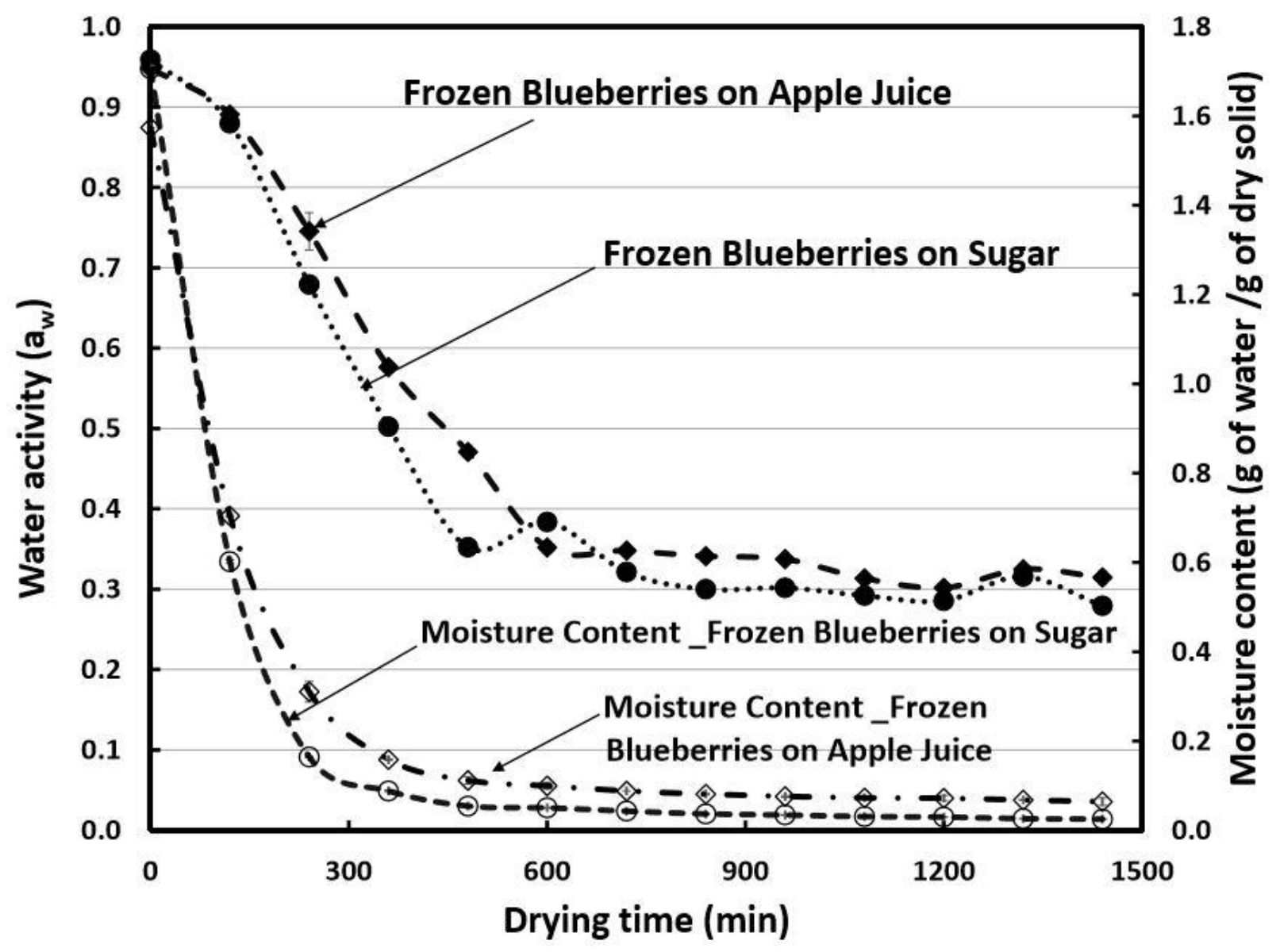

Fig. 9. Decrease in water activity of osmotically dehydrated frozen blueberries using sugarbased and apple juice-based osmotic solutions in a fruit dehydrator at $74{ }^{\circ} \mathrm{C}$ 